\title{
PELAYANAN KOMUNIKASI PERBANKAN DAN KEPUASAN NASABAH (PERSPEKTIF KOMUNIKASI ISLAM)
}

\author{
Dian Adi Perdana \\ IAIN Sultan Amai Gorontalo \\ Email : dianadiperdana@iaingorontalo.ac.id
}

\begin{abstract}
$T$ his article explains about the optimization of banking communication services that causes customer (campus community) dissatisfaction. The main source of the problem are not being able to use internet banking in banking services, the lack of employees at the nearest BTN operational office, payment schedules that are often delayed because of internet integrity connecting between the campus and the bank is broken and service dissatisfaction has not yet reached the remote area. This study is a qualitative research by doing interview, observation, and documentation in data collection. The interactive analysis model is done in a descriptive qualitative manner and the data is presented with a SWOT analysis. The conclusion is the component of customer satisfaction in the form of: responsiveness, compliance, empathy, tangible, reliability and assurance which are elements of patterns of improvement in communication services have a positive influence on customer satisfaction in using banking services. Another thing is the need to optimize the strength they have to respond to opportunities that arise from external companies.
\end{abstract}

Keywords: Service, Banking Communication, BTN Customer Satisfaction

\begin{abstract}
ABSTRAK
A rtikel ini menjelaskan tentang ketidakoptimalan pelayanan komunikasi perbankan sehingga menimbulkan ketidakpuasan nasabah (masyarakat kampus). Sumber permasalahan yakni belum bisa menggunakan internet banking/mobile banking pada layanan perbankan, minimnya pegawai di kantor operasional BTN terdekat, jadwal pembayaran sering tertunda dan mundur karena internet integrity connecting antara kampus dan bank putus dan tidakpuasan pelayanan yang belum mencapai remote area. Pendekatan penelitian secara kualitatif dengan metode studi kasus, pengumpulan data dengan wawancara, observasi dan sumber dokumentasi. Model analisis interaktif dilakukan secara kualitatif deskriptif serta data disajikan dengan analisis SWOT. Kesimpulannya adalah komponen kepuasan nasabah berupa: responsiveness, compliance, empathy, tangiable, reliability dan assurance yang merupakan unsurunsur pola peningkatan pelayanan komunikasi memiliki pengaruh positif terhadap kepuasan nasabah dalam menggunakan jasa perbankan. Hal lain adalah perlu mengoptimalkan kekuatan yang dimiliki untuk merespon peluang yang timbul dari eksternal perusahaan.
\end{abstract}

\section{Kata Kunci: Pelayanan, Komunikasi Perbankan, Kepuasan Nasabah BTN}

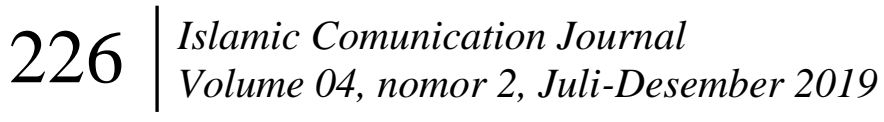




\section{PENDAHULUAN}

\section{Latar Belakang dan Permasalahan}

Komunikasi hal yang sangat penting dalam setiap elemen dan perilaku manusia, hal ini sebagai cara seseorang untuk menyampaikan pesan kepada orang lain baik secara verbal maupun nonverbal, langsung maupun tidak langsung dengan berbagai media sebagai penunjangnya. Komunikasi adalah suatu proses menyortir, memilih dan mengirim simbol-simbol yang sedemikian rupa sehingga dapat membantu pendengar dalam membangkitkan daya respon atau pemaknaan dari sebuah pemikiran yang selaras dengan yang dimaksud komunikator (Sambas, 2015 : 49). Segala sesuatu yang dilakukan manusia mempunyai potensi komunikasi, dalam komunikasi setiap orang akan mensyaratkan untuk mendapatkan titik temu dari tindakannya.

Setiap waktu dan bagian dalam kehidupan manusia pasti terjadi gejolak atau dinamika dan tidak terlepas pula dalam dunia bisnis dan usaha. Dinamika dalam lingkungan bisnis selalu menuntut setiap perusahaan baik skala makro maupun mikro untuk melakukan penyesuaian dengan keinginan pembeli atau pengguna jasa/barang dengan sebuah perubahan, inovasi dan kreasi dalam berbisnis. Penyesuaian metode dalam berbisnis akan mampu meningkatkan kinerja perusahaan secara langsung maupun tidak langsung, pola yang baik mampu terbangun dengan didasari komponen dan elemen penting dalam perusahan seperti pegawai, peraturan, sarana prasarana hingga budaya organisasi.

Salah satu komponen penting dalam peningkatan komunikasi antara komunikator dan komunikan adalan pelayanan yang optimal. Menurut Philip Kotler ada serangkaian variabel pemasaran terkendali yang dipakai oleh perusahaan untuk menghasilkan tanggapan yang dikendalikan perusahaan, dari pasar sasarannya, bauran pemasaran terdiri atas segala yang bisa dilakukan perusahaan untuk mempengaruhi permintaan produknya, yang dikenal dengan "4P", yaitu product, price, place dan promotion" (Kotler, 2009 : 189). Pelayanan komunikasi kepada pelanggan atau pembeli merupakan bagian dari promotion, yang artinya pola promosi bukan hanya menawarkan barang/jasa saja tapi tata cara seorang penjual atau penyedia jasa mampu memikat dan memiliki daya tarik bagi pelanggan dan pembeli agar mau menggunakan barang/jasa yang ditawarkan sehingga pelanggan bisa terpuaskan akan layanan yang diperolehnya.

Melihat kondisi global masa kini setiap lembaga maupun perusahaan harus mampu mengikuti arus perubahan yang terjadi semakin hari semakin cepat baik internal maupun eksternal lembaga atau perusahaan. Upaya dalam mengikuti perkembangan dan perubahan yang terjadi tersebut, bukanlah suatu hal yang mudah untuk dilalui, maka perlu adanya kerja keras dan kerjasama. Perusahaan dan lembaga yang masih memiliki pola pikir dan gerak tradisionalisme, tidak inovatif dan tidak kreatif dalam menentukan cara dan usaha, tentu saja akan menemukan banyak kesulitan dan hambatan dalam menjalankan operasional dan bisnisnya. Banyak cara, metode dan strategi dapat dilakukan oleh sebuah perusahaan atau lembaga dalam

\section{Islamic Comunication Journal Volume 4, Nomor 2, Juli-Desember 2019


rangka mencapai tujuan yang ingin dicapai yang tentunya sebagai puncak keberhasilan dan kesuksesan.

Strategi yang diterapkan perusahaan untuk di setiap bidang pun berbeda-beda, bervariasi yang tentunya perlu inovasi dimulai dari bagian produksi, distribusi, penjualan, maupun promosinya. Target perusahaan yang akan dicapai oleh suatu perusahaan atau lembaga tentunya harus didukung dengan adanya strategi dan langkah yang tepat agar perusahaan dapat mengalami peningkatan kualitas dan kuantitas usahanya. Strategi perusahaan atau lembaga dalam meningkatkan penjualannya dapat dilakukan dengan berbagai cara, salah satunya adalah dengan peningkatan strategi promosi.

Ben M. Enis sebagaimana dikutip oleh Alma, mendefinisikan promosi "as communication that inform potential customers of the existence of products, and persuade them thah those products have want satisfying capabilities" (Alma, 2007: 179). Dari teori tersebut dapat disimpulkan bahwa promosi adalah sejenis komunikasi yang memberi penjelasan yang meyakinkan calon customer, dalam komunikasi tersebut ada upaya perusahaan dalam peningkatan kinerja, peningkatan laba dan brand image perusahaan tentunya. Promosi ini merupakan bagian dari komunikasi pemasaran, komunikasi pemasaran adalah salah satu kegiatan pemasaran yang berusaha menyebarkan informasi, memengaruhi, dan atau meningkatkan pasar sasaran atas perusahaan maupun produk agar bersedia menerima, membeli, dan setia kepada produk yang ditawarkan produsen.
Industri perbankan di Indonesia sudah berkembang pesat, bahkan setidaknya terdapat 115 bank yang telah beroperasi terdiri dari bank lokal dan bank asing. Banyaknya bank yang beroperasi di negara ini membuat para calon nasabah harus cerdik dalam memilih bank yang akan dimanfaatkan jasanya oleh elemen masyarakat, yag diharapkan dana simpanan akan aman bahkan hingga dipermudah dalam memperoleh pinjaman. Fluktuatifnya suku bunga acuan telah mengakibatkan perang bunga antar bank yang membuat likuiditas di Indonesia semakin cukup ketat tanpa melihat BUKU IV, BUKU III, BUKU II bahkan BUKU I.

Berdasarkan PSAK No. 31, Bank merupakan suatu lembaga yang berperan sebagai perantara keuangan (Financial Intermediary) antara pihak-pihak yang memiliki kelebihan dana (Surplus Unit) dengan pihak-pihak yang memerlukan dana (Deficit Unit), serta sebagai lembaga yang berfungsi memperlancar lalu lintas pembayaran. Perbankan di Indonesia akan berusaha untuk hidup dan eksis dalam jangka panjang dengan berbagai strategi untuk bersaing dalam industri perbankan. Keberagaman produk bisa menjadi senjata antar bank di Indonesia, begitu juga yang dilakukan oleh BTN, produk-produk yang dimiliki oleh bank-bank di Indonesia akan membuat konsumer berfikir keras untuk memilih dimanakah dana para calon nasabah akan diinvestasikan atau sekedar menyimpan. Kepuasan nasabah merupakan sumber kekuatan bagi sebuah perusahaan, jika minimnya rasa puas yang didapat oleh nasabah, maka besar mungkin perusahaan 
tersebut akan segera koleps. Kepuasan nasabah sebagai hasil penilaian nasabah terhadap apa yang diharapkannya dengan membeli dan mengkonsumsi suatu produk atau jasa (Al Arif, 2010: 192).

Menurut Yanuar Yogatama dalam penelitiannya mengatakan bahwa kepuasan kompensasi yang diterima karyawan merupakan gambaran dari kepuasan karyawan. Setiap pekerjaan yang dilakukan oleh karyawan didasari dengan adanya kompensasi yang akan diterima sebagai motif dasar bekerja. Bahkan menurutnya kompensasi bukan hanya berupa finansial tapi kompensasi non finansial seperti cuti, lembur, promosi jabatan hingga lingkungan kerja yang kondusif menjadi faktor utama kepuasan karyawan dan ini terjadi di Bank BTN Cabang Utama Tangerang (Yogatama, 2013: 117).

Kepuasan baik yang dirasakan karyawan maupun pelanggan menjadi nilai terpenting dalam membangun brand BTN. Bank BTN memiliki kerjasama Co-Branding berupa Kartu Tanda Mahasiswa dengan Fakultas Dakwah dan Komunikasi Universitas Islam Negeri Walisongo Semarang. Peneliti melakukan survey kepada para mahasiswa/i Fakultas Dakwah dan Komunikasi Universitas Islam Negeri Walisongo Semarang dan ditemukan bahwa ketidakpuasan dari para nasabah masih cukup tinggi. Tingkat kepuasan merupakan fungsi dari perbedaan antara kinerja yang dirasakan dengan harapan. Masih tingginya ketidakpuasan ini disebabkan dengan minimnya pelayanan nasabah dalam menggunakan jasa perbankan BTN (Survey Lokal).
Minimnya ketidakpuasan nasabah menjadi masalah besar bagi BTN yang kedepannya akan berdampak besar, Puas dan tidak puasnya nasabah bisa dipengaruhi oleh proses penilaian dan pemilihan dari berbagai pilihan produk perusahaan sesuai dengan kepentingan customer dengan menetapkan suatu pilihan yang dianggap paling menguntungkan.

Pelayanan komunikasi perbankan yang menjadi sumber permasalahan yakni belum bisa menggunakan internet banking/mobile banking untuk pembayaran SPP semester dan layanan perkuliahan lain pun mahasiswa harus membayar langsung ke kantor-kantor pelayanan BTN terdekat dengan tempat tinggal, Minimnya pegawai di kantor operasional BTN terdekat, sehingga harus berantrian panjang hingga keluar, Jadwal pembayaran sering tertunda dan mundur karena internet integrity connecting antara kampus dan bank putus dan faktor lainnya yaitu kepuasan pelayanan yang dapat mencapai hingga daerah-daerah terpencil (remote area).

Sejalan dengan permasalahan di atas, Muyadinata menjelaskan dalam penelitian yang dilakukan di perusahaan yang sama yakni PT Bank Tabungan Negara (Persero) Tbk dengan kantor cabang yang berbeda yakni Kantor Cabang Bandar Lampung. Ia menjelaskan dalam penanganan keluhan yang dialami para nasabah BTN harus ditunjukkan secara cepat dan tepat dengan sebuah pembawaan perhatian, keperihatinan dan kekecewaan akan ketidakpuasan nasabah, sehingga berimplikasi pada kepuasan dan loyalitas nasabah atas perusahaan dengan selalu menggunakan 
Pelayanan Komunikasi Perbankan Dan...hal.226-243

produk-produk BTN (Mulyadinata, 2015: 36).

Dari uraian masalah di atas, maka peneliti akan memfokuskan penelitian ini dengan rumusan: Bagaimana pola pelayanan komunikasi antara perbankan kepada nasabah Bank BTN; Bagaimana pola meningkatkan kepuasan nasabah oleh Bank BTN; dan Bagaimana tanggapan nasabah terkait kepuasan dalam penggunaan jasa perbankan Bank BTN yang dijabarkan dalam analisis SWOT perusahaan melalui produkproduk BTN yang digunakan nasabah.

Berdasarkan pada rumusan masalah di atas, maka tujuan penelitian adalah untuk mengetahui pola pelayanan komunikasi yang dilaksanakan oleh Bank BTN Cabang Kota Semarang, untuk mengetahui pola meningkatkan kepuasan nasabah oleh Bank BTN serta untuk mengetahui tanggapan nasabah terkait kepuasan dalam menggunakan jasa produk perbankan Bank BTN Cabang Kota Semarang.

\section{TEORI DAN KAJIAN PUSTAKA}

\section{Pelayanan Komunikasi}

Pelayanan Komunikasi merupakan penunjang keberhasilan suatu pelayanan yang diberikan oleh suatu perusahaan atau organisasi kepada masyarakat yang dipengaruhi oleh berbagai faktor internal dan eksternal. Menurut Moenir, pelayanan merupakan suatu kegiatan yang dilakukan oleh seseorang atau sekelompok orang dengan landasan tertentu di mana tingkat pemuasannya hanya dapat dirasakan oleh orang yang melayani atau orang yang dilayani, tergantung kepada kemampuan penyedia jasa dalam memenuhi harapan pengguna (Moenir, 2002: 34). Adapun faktor-faktor yang mempengaruhi pelayanan tersebut adalah tingkah laku yang sopan, cara penyampaian dengan cepat dan keramahtamahan, ada juga faktor lainnya yang tidak kalah penting dalam keberhasilan suatu pelayanan yaitu adanya kesadaran, peraturan, organisasi, keterampilan pekerja dan sarana prasarana penunjang.

Menurut Ivancevich, pelayanan merupakan produk-produk tak kasat mata (tidak dapat diraba) yang melibatkan usahausaha manusia dan menggunakan peralatan. Dengan hal ini aktifitas yang bersifat tidak kasat mata yang terjadi sebagai akibat adanya interaksi antara konsumen dan karyawan atau hal lain-lain yang disediakan oleh perusahaan pemberi layanan yang dimaksudkan untuk memecahkan permasalahan konsumen atau pelanggan. Pelayanan biasanya menggambarkan karakteristik suatu produk yang meliputi responsiveness, compliance, empathy, tangiable, reliability dan assurance baik secara simultan maupun partial (Wibisino, 2006: 95).

Pelayanan komunikasi akan selalu ada kaitannya dengan komunikasi pemasaran, dan komunikasi pemasaran mempunyai beberapa fungsi yaitu sebagai berikut:

a. Konsumen dapat diberitahu atau ditunjukkan bagaimana dan mengapa sebuah produk digunakan. Selain itu juga member tahu dimana serta kapan produk tersebut digunakan.

b. Konsumen dapat mengetahui tentang siapa yang membuat produk tersebut dan apa keunggulan produk tersebut 
dibandingkan produk lain yang sejenis.

Kotler menyebutkan bahwa dewasa ini terdapat suatu pandangan baru yang memandang komunikasi sebagai dialog interaktif antara perusahaan dengan pelanggannya yang berlangsung selama tahap prapenjualan, penjualan, konsumsi, dan pasca konsumsi. Proses komunikasi harus berjalan seefektif mungkin agar tujuan komunikasi yang telah ditetapkan dapat tercapai. (Kotler, 2007: 57)

Adapun elemen-elemen dalam proses komunikasi dibagi menjadi sembilan unsur, yakni dua unsur di antaranya adalah pihak utama dalam komunikasi yaitu pengirim (komunikator) dan penerima (komunikan), dua unsur selanjutnya adalah alat komunikasi utama, pesan dan media, sementara empat unsur selanjutnya merupakan fungsi komunikasi utama yakni pengkodean (encoding), penguraian kode (decoding), tanggapan (response), dan umpan balik (feedback). Unsur terakhir dalam sistem tersebut adalah gangguan (noise) yaitu pesanpesan acak dan bertentangan yang dapat mengganggu komunikasi yang diharapkan. Kesembilan ini saling berkaitan dan selalu digunakan dalam kehidupan sehari-hari.

Pelayanan Komunikasi dalam Islam adalah suatu keharusan dalam implementasi operasional perusahaan yang berbasis syari'ah. Islam menekankan keabsahan suatu pelayanan yang sesuai dengan konsumen adalah dibuktikan dengan tingkat kemaksimalan kepuasan yang dirasakan oleh pelanggan. Dalam konsep pelayanan secara Islam terdapat nilai-nilai kemanusiaan yang penting dalam menjaga harmonisasi umat yakni Al-Layin atau lemah lembut, Allah telah berfirman dalam Surat Ali-Imran ayat 159:

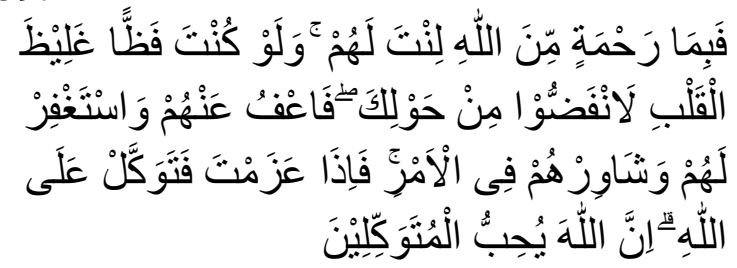

Artinya : Maka disebabkan rahmat dari Allahlah kamu berlaku lemah lembut terhadap mereka. Sekiranya kami bersikap keras lagi berhati kasar. Tentulah mereka menjauhkan diri di sekelilingmu. Karena itu, maafkanlah mereka. Mohonkanlah ampub bagi mereka dan bermusyawarahlah dengan mereka dalam urusan itu (yakni urusan peperangan dan hal-hal duniawiyah lainnya). Kemudian apabila kamu telah membulatkan tekad, maka bertawakallah kepada Allah SWT. Sesungguhnya Allah SWT menyukai orang-orang yang tertawakal kepada-Nya.

Perihal ayat di atas, Ibnu Katsir menafsirkan dalam kitabnya bertutur kata yang lembutlah laksana sifat Rasulullah SAW yang diutus di dunia oleh Allah SWT untuk selalu berlaku baik, bertutur kata yang sopan dan bersikap ramah kepada sesame manusia sebagai bentuk implementasi akhlaqul karimah (Katsir, 2002 : 233).

\section{Islamic Comunication Journal Volume 4, Nomor 2, Juli-Desember 2019


Pelayanan Komunikasi Perbankan Dan...hal.226-243

\section{Kepuasan Nasabah}

Kepuasan merupakan tingkat perasaan dimana seseorang mengatakan hasil perbandingannya antara hasil kerja atau produk atau jasa yang diterima dengan apa yang diharapkan (Kotler, 2000: 36). Adapula pendapat Engel, kepuasan nasabah merupakan evaluasi purnabeli dimana alternative yang dipilih sekurang-kurangnya memberikan hasil (outcome) sama atau melampaui harapan nasabah, sedangkan ketidakpuasan timbul apabila hasil yang diperoleh tidak memenuhi harapan nasabah (Engel, 1992: 11).

Dari kedua teori di atas Philip Kotler menyatakan bahwa kepuasan nasabah itu kepuasan dan ketidakpuasan yang merupakan respon nasabah terhadap evaluasi kesesuaian (disconfirmation) yang dirasakan antara harapan sebelumnya (norma, kinerja dan lainnya) dengan kinerja yang telah diaktualisasi berupa produk yang dirasakan setelah pemakaiannya. Demi memenuhi keinginan nasabah tersebut terdapat dimensidimensi yang perlu diimplementasikan oleh perusahaan dalam bentuk strategi bauran pemasaran, bahwa nilai-nilai nasabah dapat diciptakan melalui: Dimensi Produk, Layanan Penjualan dan Layanan Purnajual dan Keluhan.

Penelitian terkait pelayanan komunikasi perbankan yakni, pertama penelitian yang dilakukan oleh Putri Dwi Cahyani terkait Tingkat Kepuasan Nasabah Terhadap Kualitas Pelayanan Perbankan Syariah di Yogyakarta ditemukan bahwa kualitas layanan bank serta kepuasan yang dirasakan nasabah kepada bank syariah sudah di atas moderat dan faktor-faktor kualitas jasa yang memberikan kepuasan nasabah adalah responsiveness, compliance, empathy, tangiable, reliability dan assurance. Dalam analisis varian telah disimpulkan bahwa persepsi nasabah terhadap kualitas empat bank syariah (BTN Syariah, BNI Syariah, BPD DIY dan Muamalat) dianggap tidak signifikan dan dianggap tidak ada perbedaan, yang artinya kepuasan nasabah tidak ada perbedaan pula (Cahyani, 2016 : 151).

Kedua, Penelitian dengan judul pengaruh kualiatas pelayanan terhadap kepuasan nasabah di PT Bank Central Asia Tbk Cabang Undaan Surabaya karya Yulian Belinda Ambarwati menyimpulkan terdapat pengaruh secara serempak responsiveness, compliance, empathy, tangiable, reliability dan assurance terhadap kepuasan nasabah PT Bank Central Asia Tbk Cabang Undaan Surabaya, serta dari masing faktor-faktor kualitas jasa tersebut terdapat pengaruh secara partial terhadap kepuasan nasabah PT Bank Central Asia Tbk Cabang Undaan Surabaya (Ambarwati, 2014 : 83).

Kepuasan nasabah merupakan hal yang sangat penting, dan hal ini dibangun dari asas kepercayaan pelanggan kepada penyedia jasa atau barang. Karena kepercayaan pelanggan merupakan amanah yang tidak boleh disiasiakan. Kepuasan nasabah diperoleh dengan profesionalitas dan efektifitas pekerjaan yang dilakukan oleh penyedia jasa dan barang. Sejatinya kepuasan nasabah adalah bagian dari implikasi dari pesan moral yang disampaikan oleh komunikator yang

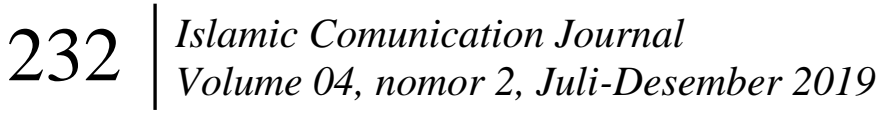


direspon positif maupun negatif oleh komunikan. Dalam Al-Qur'an Surat AlMaidah ayat 1 , Allah berfirman:

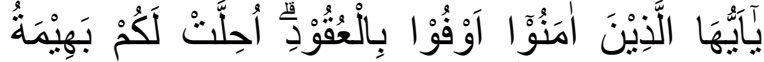

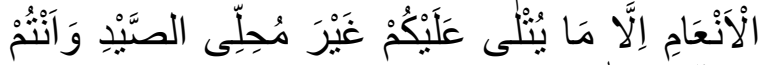

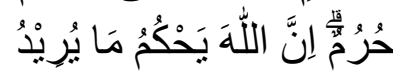

Artinya : Hai orang-orang yang beriman, penuhilah aqad-aqad (berupa perjanjian mencakup prasetia kepada Allah SWT dan perjanjian kepada sesama manusia). Dihalalkan bagimu binatang ternak, kecuali yang akan dibacakan kepadamu (yang demikian itu), dengan tidak menghalalkan berburu ketika kamu sedang mengerjakan haji. Sesungguhnya Allah SWT menetapkan hukum-hukum menurut yang dikehendakinya.

Dalam ayat ini, dijelaskan bahwa sebuah perjanjian merupakan kunci dasar seorang pembisnis atau wirausaha atau penyedia jasa dan barang membangun rasa kepercayaan pada pelanggannya, yang dikemudian hari akan berimplikasi pada kepuasan yang mereka rasakan atas pemberian dan penyajian yang disajikan oleh penjual. Bahkan Allah SWT menjelakan pula dalam surat At-Taubah ayat 59:

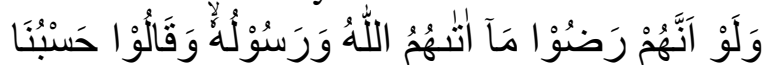

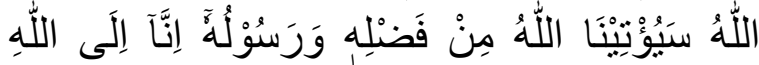
رَغِبُوْنَع

Artinya : Jikalau mereka sungguhsungguh ridlo dengan apa yang diberikan Allah SWT dan Rasul-Nya keapda mereka, dan berkata "Cukuplah Allah bagi kami, Allah SWT akan memberikan sebagian dari karunia-Nya dan demikian (pula) Rasul-Nya, Sesungguhnya kami adalah orang-orang yang berharap kepada Allah SWT" (tentulah yang demikian lebih baik bagi mereka).

Dalam Tafsif Misbah, ayat di atas sangat berkorelasi dengan ayat setelahnya yakni pembagian zakat harus didistribusikan secara merata kepada 8 asnaf dengan dasar ketidakmampuan mustahik dengan berbagai sebab karena ketidakadaan lapangan pekerjaan, maupun kemampuan yang dimiliki tidak mencukupi kebutuhan keluarga yang ditanggungnya (Shihab, 2002: 142).

Demikian halnya bahwa ayat di penafsiran di atas menjelaskan pentingnya kepuasan yang telah dirasakan oleh seorang hamba atas apa yang telah diberikan Allah SWT. Hal ini serupa antara penjual dengan pembeli, seorang pembeli terpuaskan jika pelayanan penjual memenuhi keinginan dan kebutuhan pembeli. Maka oleh karena itu, kepuasan pelanggan begitu sangat penting dalam optimalisasi pelayanan dan komunikasi dalam berbisnis.

\section{METODE PENELITIAN}

Peneliti melakukan penelitian secara kualitatif, dengan metode yang digunakan adalah studi kasus. Studi kasus merupakan suatu inkuiri empiris yang menyelidiki fenomena dalam konteks kehidupan nyata, bilamana batas-batas antara fenomena dan konteks tak tampak dengan tegas dan di mana, multi sumber bukti dimanfaatkan (Yin, 2008: 18). Studi kasus difokuskan pada pola kepuasan nasabah dengan faktor-faktor pelayanan komunikasi perbankan BTN. Pengumpulan data dilakukan dengan melalui wawancara dengan beberapa informan terpilih untuk menggali data primer. Dalam memperoleh data-data penguat, peneliti

\section{Islamic Comunication Journal Volume 4, Nomor 2, Juli-Desember 2019


Pelayanan Komunikasi Perbankan Dan...hal.226-243

menambahkan data-data studi literatur, dokumen dan observasi langsung.

Data yang terkumpul akan diolah melalui klasifikasi data sesuai dengan karakteristik dan indikatornya untuk diintegrasikan. Peneliti menggunakan model analisis interaktif, pertama melakukan reduksi data kualitatif hasil observasi dan wawancara, kedua melakukan penyajian atau publikasi data, dan ketiga menarik kesimpulan dari sajian data dan disajikan pula dengan analisa SWOT. Dalam analisa SWOT akan menbahas bagaimana situasi perusahaan serta strategi perusahaan yang disajikan sesuai data dari informan.

Menurut Rangkuti, Analisis SWOT digunakan untuk melihat situasi yang di kemudian kesempatan digunakan untuk merencanakan sesuatu agar menjadi lebih baik yang tentunya akan menjadi skala prioritas pengembangan bisnis, mendeskripsikan secara jelas bagaimana peluang dan ancaman eksternal yang dihadapi serta kekuatan dan kelemahan yang dimiliki (Rangkuti, 2009: 31). Peneliti mengambil lokasi penelitian di UIN Walisongo Semarang khususnya mahasiswa/i Fakultas Dakwah dan Komunikasi sebagai informan dalam memahami kepuasan nasabah terhadap pelayanan komunikasi perbankan dari BTN Cabang Semarang yang telah melakukan cobranding berupa KTM.

\section{HASIL DAN PEMBAHASAN}

Dalam penelitian ini telah dirumuskan pertanyaan-pertanyaan yakni bagaimana pola pelayanan komunikasi antara perbankan kepada nasabah Bank BTN, bagaimana pola meningkatkan kepuasan nasabah oleh Bank BTN dan bagaimana tanggapan nasabah terkait kepuasan dalam penggunaan jasa perbankan Bank BTN.

\section{Pola Pelayanan Komunikasi antara Perbankan kepada Nasabah Bank BTN}

Peneliti memperoleh pola pelayanan komunikasi yang di dalamnya terjadi proses komunikasi, dimulai ketika pengirim mengirimkan pesan. Pengirim harus mengetahui siapa yang ingin dicapai dan tanggapan apa yang diinginkan pengirim dalam hal ini perusahaan yang mengirimkan pesan tentang produk yang telah dihasilkannya kepada pelanggannya. Pesan ini disampaikan dengan kode-kode yang sesuai dengan sasaran pelanggannya melalui media-media yang dimiliki BTN.

Bank BTN Kantor Cabang Semarang menjalankan bisnis jasa keuangan perbankan dengan produk berupa jasa layanan milik BTN, yaitu: KPR, Perbankan Konsumer, Perbankan Komersial, Perbankan Syariah, Treasury \& Asset Management. Dalam upaya dalam peningkatan trust dari para nasabah peneliti mendapatkan beberapa poin dari para informan bahwa responsiveness, compliance, empathy, tangiable, reliability dan assurance yang merupakan pola peningkatan pelayanan komunikasi memiliki pengaruh positif terhadap kepuasan nasabah dalam menggunakan jasa perbankan, dengan ini yang harus dimulai dan diperhatikan dengan mengutamakan kebutuhan konsumen atau nasabah.

Pada kenyataannya, tidak semua konsumen mengetahui bagaimana cara untuk

\section{$234 \mid \begin{aligned} & \text { Islamic Comunication Journal } \\ & \text { Volume 04, nomor 2, Juli-Desember } 2019\end{aligned}$}


memenuhi kebutuhannya atau tidak menyadari adanya produk yang mampu memenuhi kebutuhannya. Konsumen mungkin akan aktif mencari informasi tersebut. Pada sisi lain, produsen menyadari situasi tersebut sehingga berusaha mengirim dan menyebarkan informasi tentang produk (adanya produk baru, manfaat dan kegunaan produk, harga, dimana dan kapan dapat dibeli, dan sebagainya) kepada mereka.

Strategi perusahaan dala hal ini BTN dalam meningkatkan pelayanan komunikasi harus merupakan inisiatif dan komitmen dari manajemen puncak yakni dewan eksekutif dan dewan komisaris. Manajemen puncak harus memimpin perusahaan untuk meningkatkan kinerja kualitas pelayanan komunikasi secara maksimal. Dalam melaksanakan strategi perusahaan diperlukan proses perencanaan strategi yang harus mencakup pengukuran dan tujuan kualitas yang dipergunakan dalam pengarahkan perusahaan untuk mencapai visinya, adanya proses review merupakan salah satu alat yang paling efektif dan efisien bagi para jajaran manajemen perusahaan untuk mengubah perilaku operasional.

Proses ini merupakan suatu mekanisme yang menjamin adanya perhatian konstan dan terus menerus untuk mencapai tujuan kualitas. Implementasi strategi dalam organisasi dipengaruhi oleh proses komunikasi dalam perusahaan secara horizontal dan vertical, komunikasi harus dilakukan dengan karyawan, pelanggan dan stakeholder perusahaan lainnya (Tjiptono, 1996: 75). Hal ini membuat BTN harus selalu bersedia mendengarkan dan menyajikan keluhan dan saran konsumen dan berusaha untuk memenuhinya karena dimensi tersebut berpengaruh dalam peningkatan kepuasan nasabah. Nasabah meskipun telah mengetahui informasi (well informed), belum tentu nasabah akan memilih atau membeli kembali produk perusahaan (karena belum bersedia membeli sekarang, adanya produk lain yang sejenis, adanya barang pengganti, merasa harga terlalu mahal, kurang dapat mengetahui kebutuhan, dan sebagainya). Produsen perlu membujuk dan mengingatkan selalu mereka agar bersedia membeli atau memilih kembali produk perusahaan. Untuk semua itu, produsen perlu melakukan kegiatan promosi dengan berkomunikasi kepada konsumen karena kegiatan promosi pada dasarnya adalah proses komunikasi antara produsen dengan konsumen, maka pemahaman komunikasi bagi produsen sangat diperlukan

Nasabah akan banyak hal yakni kualitas produk, kemudian kualitas pelayanan, harga, biaya dan emosional dari pelayanan BTN kepada nasabah. Ini yang akan berdampak pada proses pemilihan produk dan pemilihan merek yang dilakukan oleh mahasiswa/i Fakultas Dakwah dan Komunikasi UIN Walisongo Semarang. Dalam dimensi kebutuhan konsumen, pelayanan komunikasi menjadi faktor yang mempengaruhi kepuasan nasabah dalam menggunakan jasa perbankan. BTN memfokuskan pada setiap kebutuhan nasabah bukan permintaan nasabah, karena kepuasan nasabah akan hadir ketika kebutuhan nasabah terpenuhi bahkan sebelum mereka berkeinginan kuat, sehingga nasabah memberikan keputusan terbaiknya kepada BTN.

\section{Islamic Comunication Journal Volume 4, Nomor 2, Juli-Desember 2019


Pelayanan Komunikasi Perbankan Dan...hal.226-243

Perusahaan diharapkan untuk memberikan ekspektasi nasabah dengan menentukan kebutuhan konsumen terlebih dahulu kemudian merancang sebuah strategi pelayanan untuk membuat nasabah nyaman dan puas dengan BTN. Hasil penelitian ini juga diperoleh data bahwa pelayanan berpengaruh terhadap kepuasan pelanggan, yang berarti bahwa semakin besar pengaruh pelayanan, maka semakin besar pula kepuasan yang dicapai oleh pelanggan tersebut. Pelayanan memberikan pengaruh dan berdampak positif terhadap kepuasan pelanggan. Seorang nasabah akan puas jika mendapatkan pelayanan yang sesuai dijanjikan, terpercaya, akurat, cepat dan ramah sehingga menimbulkan kepercayaan dan keyakinan pada nasabah untuk menyimpan dananya di bank, kemampuan pelayanan bisa juga disebut melayani secara cepat dan tepat, memiliki pengetahuan dan kemampuan yang baik.

\section{Pola Peningkatan Kepuasan Nasabah oleh Bank BTN}

BTN memiliki fokus bisnis inti pada sektor KPR yang saat ini masing dikembangkan secara besar-besaran bahkan pemerintah memberi dukungan besar dalam berupaya Program Sejuta Rumah untuk rakyat, BTN menawarkan berbagai paket kredit pemilikan rumah kepada masyarakat umum dengan bunga yang relatif rendah serta proses yang mudah seperti Program Untuk Rakyat DP, KPR BTN Subsidi, dan KPR BTN. BTN menggunakan lima dimensi dalam meningkatkan kepuasan nasabah terhadap pelayanan komunikasi yang dilakukan, BTN mengharapkan pelayanan yang diberikan kepada nasabah dirasa lebih mudah, lebih baik, tepat sasaran, akurat dan ramah sesuai yang diharapkan oleh nasabah.

$$
\text { Pendapat Pasuraman dalam }
$$

Eninurkhayatun (2017 : 34), Peningkatan kepuasan nasabah melalui pelayanan komunikasi terdapat lima faktor utama dalam mengukur dimensi tersebut : Responsiveness, yaitu kemauan untuk membantu pelanggan dan melaksanakan service dengan tepat, Tangibles, yaitu penampilan dari fasilitas fisik, peralatan dan materi komunikasi, Empathy, berupa pemberian perhatian yang sungguh-sungguh dari pemberi pelayanan kepada konsumen secara individual, Assurance, yaitu dimensi mutu pelayanan yang berupa adanya jaminan yang mencakup pengetahuan dan keterampilan, kesopanan dan keramahan, serta Reliability, yaitu kemampuan untuk melaksanakan pelayanan yang dijanjikan. Berdasarkan lima dimensi tersebut akan diketahui pengaruh pelayanan komunikasi terhadap kepuasan nasabah.

Lima pola peningkatan yang dilakukan oleh BTN dalam meningkatkan pelayanan komunikasinya kepada nasabah yaitu mahasiswa/i Universitas Islam Negeri Walisongo ialah:

a. Responsiveness, yaitu dengan meningkatkan kemampuan, keterampilan yang dimiliki oleh BTN Cabang Semarang khususnya untuk membantu para nasabah dalam setiap keluhan dan upaya dalam memberikan solusi dan pelayanan yang cepat, tepat dan tanggap sesuai dengan kebutuhan. 
b. Tangibles, yaitu meningkatkan sarana dan fasilitas fisik para pegawai BTN sebagai penyedia jasa perbankan kepada nasabah, termasuk peralatan kantor, perlengkapan kerja, penampilan pegawai, sarana komunikasi hingga tenaga administrasi di BTN Cabang Semarang.

c. Empathy, BTN melakukan peningkatkan rasa kepedulian dan berusaha untuk mampu memberikan perhatian pribadi kepada setiap nasabah, dengan meliputi kemudahan dalam melakukan hubungan, komunikasi yang baik, perhatian pribadi dan pemahaman atas kebutuhan nasabah di BTN.

d. Assurance, sebagai jaminan dan kemampuan perusahaan terus ditingkatkan untuk setiap nasabah, sifat respect, etika yang baik dan trust bagi nasabah yang dimiliki oleh setiap pekerja BTN Cabang Semarang, sehingga menimbulkan kepercayaan dan keyakinan nasabah.

e. Reliability, BTN melakukan peningkatan kemampuan dalam memberikan pelayanan yang disajikan dengan segera, akurat, tepat waktu sesuai dengan yang dijanjikan dalam setiap kegiatan promosi dan selalu memberikan kepuasan nasabah secara optimal.

Kelima pola di atas ditemukan bahwa terdapat upaya-upaya BTN dalam memberikan layanan yang terbaik dan paling relevan dengan kebutuhan dan keinginan nasabah sehingga nasabah merasa puas terbantu oleh perusahaan. Nasabah tidak ragu untuk melakukan re-purchase produk perbankan milik BTN yang ke depannya akan meningkatnya rasa trust nasabah terhadap perusahaan hingga mampu menimbulkan brand image yang positif terhadap segala produk, promosi dari perusahaan perbankan ini.

Trust yang hadir dari nasabah sebagai modal hidup BTN untuk membiayai segala kebutuhan perusahaan, kepuasan nasabah sebagai persepsi dan harapan selama nasabah melakukan seluruh transaksi di BTN dalam bentuk pelayanan komunikasi yakni ketepatan pelayanan, keterbukaan informasi, kemudahan dalam bertransaksi dan komunikasi antara nasabah dan pegawai perbankan BTN. Kepuasan nasabah sebagai efek langsung dari komunikasi pemasaran terpadu merupakan tahap dalam proses pengambilan keputusan pembeli di mana konsumen benar-benar menggunakan jasa perbankan. Rasa kepuasan nasabah merupakan suatu kegiatan individu yang secara langsung terlibat dalam mendapatkan dan mempergunakan barang atau produk yang ditawarkan.

\section{Analisis SWOT terkait Kepuasan Nasabah Terhadap Penggunaan Jasa Perbankan Bank BTN}

Dalam dunia usaha selalu terjadi persaingan yang ketat dan membuat perusahaan harus selalu siap dan terampil dalam menerapkan strategi dan kebijakan perusahaan. Setiap perusahaan harus memiliki strategi dan pengembangan usaha yang dilakukan secara terus menerus. Konsep 
Pelayanan Komunikasi Perbankan Dan...hal.226-243

pengembangan strategi selalu berkaitan dengan masalah bagaimana menetapkan bentuk penawaran pada segmen pasar tertentu. Hal ini dapat terpenuhi dengan penyediaan suatu sarana yang sering disebut sebagai basis strategi, yang mencakup produk, harga, distribusi dan komunikasi pemasaran (Hasan, 2010: 31).

Dalam proses komunikasi perlu dilakukan pengembangkan yang efektif dapat melalui beberapa tahapan-tahapan, antara lain: mengidentifikasi pendengar sasaran, menentukan tujuan-tujuannya, memilih salurannya, menetapkan anggarannya, merancang pesannya, memutuskan bauran media yang dipilih, mengukur hasilnya, dan mengelola komunikasi secara baik sehingga tersampaikan dengan maksimal kepada para komunikan. Kepuasan penggunaan jasa suatu perusahaan memiliki efek terhadap perilaku khalayak sasaran (konsumen) sangat dipengaruhi oleh berbagai faktor, diantaranya faktor kebudayaan, sosial, pribadi, dan psikologi dari konsumen. Selain itu juga dipengaruhi oleh beberapa rangsangan komunikasi khususnya pada proses pemasaran, seperti unsur-unsur di dalam yaitu produk, harga distribusi, dan promosi serta rangsangan lainnya, yaitu perekonomian, teknologi, politik dan budaya.Sebagian besar faktor-faktor tersebut adalah faktor-faktor yang tidak dapat dikendalikan oleh pemasar, tetapi harus benar-benar dapat diperhitungkan (Yuliana, Hidayat, \& Tresnati, 2016: 47).

Seorang komunikator mempunyai kemampuan untuk melakukan perubahan sikap, pendapat dan tingkah laku komunikasi melalui mekanisme daya tarik jika pihak komunikan merasa bahwa komunikator ikut serta dengannya. Untuk menghasilkan perubahan sikap yang diinginkan, public relations menggunakan saluran media massa. Sebagai sarana komunikasi, berbagai bentuk media massa, seperti surat kabar, radio, televisi sangat menentukan dalam perubahan sikap seseorang. Pesan yang disampaikan lewat media dan fasilitas Bank BTN Cabang Kota Semarang mengandung informasi yang penting untuk diketahui oleh nasabahnya. Format pesan merupakan faktor penting yang menentukan menarik atau tidaknya pesan dalam suatu iklan.

Dalam tulisan ini, peneliti telah memperoleh data-data dan informasiinformasi melalui teknik wawancara, observasi dan dokumentasi. Maka untuk mengetahui pembahasan di atas peneliti menganalisis dan memfokuskan aspek-aspek terpenting serta skala prioritas bisnis pada kekuatan, kelemahan yang dimiliki BTN serta peluang dan ancaman yang hadir dari eksternal perusahaan terkait penggunaan Jasa Perbankan Bank BTN cabang Kota Semarang yang berimplikasi terhadap Kepuasan Nasabah, di antaranya yaitu :

1) Faktor Internal

a) Strengths (Kekuatan-kekuatan)

Kekuatan (Strength) adalah sumber daya, keterampilan dan keunggulan lain relatif terhadap pesaing dan kebutuhan dari pasar suatu perusahaan (W. T. Amin, 1994 : 75). Kekuatan-kekuatan yang dimiliki Bank BTN Cabang Kota Semarang, ialah : 
Lokasi kantor yang strategis untuk melakukan proses pemasaran produk.

Dalam hal penghimpunan dana, produk tabungan batara merupakan produk unggulan yang ada di Bank BTN Cabang Kota Semarang.

$>$ Memiliki brand image yang cukup kuat dipasaran.

$>$ Pelayanan yang baik dan cepat. Adanya bonus yang berupa program berhadiah langsung.

Bebas adminitrasi bulanan.

b) Weaknesses

(Kelemahankelemahan)

Kelemahan (weakness) adalah keterbatasan atau kekurangan dalam sumberdaya alam, keterampilan dan kemampuan yang secara serius menghalangi kinerja efektif suatu perusahaan (W. T. Amin, 1994 : 75). Kelemahan-kelemahan yang dimiliki Bank BTN Cabang Kota Semarang, ialah :

Fasilitas-fasilitas perbankan bagi nasabah (ATM, SMS Banking dan lain-lain) yang tersedia masih terbatas.

> Kurangnya SDM dalam bidang pemasaran.

> Promosi produk masih minim.

2) Faktor Eksternal

a) Opportunities (Peluang-peluang)

Peluang (Opportunity) adalah situasi atau kecenderungan utama yang menguntungkan dalam lingkungan perusahaan (W. T. Amin,
1994 : 74). Peluang-peluang yang dimiliki Bank BTN Cabang Kota Semarang, ialah :

Potensi pasar yang sangat baik.

Pertumbuhan pasar yang sangat tinggi.

BTN Cabang Kota Semarang merupakan bank BTN BUMN.

Letak lokasi Bank BTN Cabang Kota Semarang yang dekat dengan lingkungan pendidikan yakni UIN Walisongo Semarang.

Kerjasama dengan instansiinstansi /pemerintah/developer

b) Threats (Ancaman-ancaman)

Ancaman (Threat) adalah situasi atau kecenderungan utama yang tidak menguntungkan dalam lingkungan perusahaan (W. T. Amin, 1994 : 74). Ancaman-ancaman yang dimiliki Bank BTN Cabang Kota Semarang, ialah :

$>$ Persaingan antar produk perbankan semakin ketat.

Banyaknya pilihan produk perbankan yang variarif (kompetitor).

Strategi bisnis mudah ditiru.

Data-data di atas menunjukkan bahwasanya Bank BTN menjalankan bisnis dipengaruhi oleh beberapa faktor yang berasal dari kondisi, waktu, situasi, peristiwa dan pengaruh-pengaruh yang memiliki kaitan dalam kelancaran pemasaran produknya sehingga minati dan digunakan oleh para nasabah dan menghasilkan kepuasan nasabah.

Kepuasan nasabah Bank BTN

Cabang Kota Semarang dalam penggunaan

Islamic Comunication Journal Volume 4, Nomor 2, Juli-Desember 2019 
Pelayanan Komunikasi Perbankan Dan...hal.226-243

jasa perbankan memiliki enam elemen dapat dideskripsikan dengan memanfaatkan analisis SWOT, maka akan muncul strategistrategi baru, sebagai berikut:

1) Strategi Kekuatan dan Mengoptimalkan Kesempatan (S - O) Dengan memanfaatkan kekuatan-kekuatan yang dimiliki Bank BTN Cabang Kota Semarang, maka diharapkan dapat mengoptimalkan kesempatan-kesempatan yang ada pada proses pelayanan komunikasi produk di Bank BTN Cabang Kota Semarang untuk dapat memberikan kepuasan pada nasabah.

Kelebihan atau kekuatan itu memberikan manfaat yang baik dan maksimal terhadap pemberian jasa layanan komunikasi produk-produk Bank BTN Cabang Kota Semarang kepada seluruh nasabah, sehingga mampu memenuhi kepuasan nasabah

2) Meminimalisir Kelemahan dan Mengoptimalkan Kesempatan (WO)

Dengan mengetahui peluangpeluang serta kelemahan-kelemahan yang dimiliki Bank BTN Cabang Kota Semarang dan memungkinkan hal itu terjadi di kemudian hari, maka pihak Bank BTN Cabang Kota Semarang harus menyiapkan senjata atau strategi pelayanan dengan sikap antisipatif dan aktualisasi tekhnologi, informatif dan komunikatif yang ampuh untuk mengantisipasi hal-hal yang akan terjadi.

\begin{tabular}{l|l}
240 & $\begin{array}{l}\text { Islamic Comunication Journal } \\
\text { Volume 04, nomor 2, Juli-Desember } 2019\end{array}$
\end{tabular}

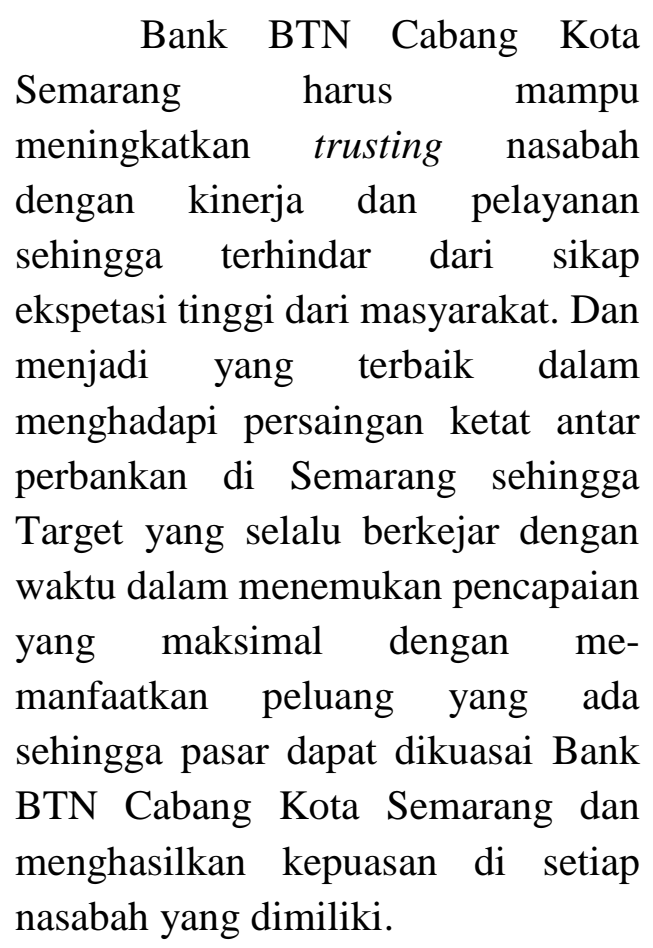

3) Strategi Kekuatan dan Menghindari Ancaman $(\mathrm{S}-\mathrm{T})$

Dengan demikian, dapat dikatakan bahwa proses pelayanan yang dilakukan oleh Bank BTN Cabang Kota Semarang memiliki kekuatan tersendiri sebagai strategi bisnisnya. Strategi-strateginya akan berpengaruh secara signifikan dalam memberikan kepuasan nasabah.

Strateginya yakni menerapkan pemasaran produk dengan metode jemput bola, mempertahankan ciri khas dan kualitas pelayanan pada produk dan menambah program-program berhadiah bagi nasabah, dan mengembangkan berbagai variasi produk agar menarik Sehingga apa saja yang hal menjadi sumber kekuatan dapat menghambat dan mencegah datangnya ancaman bisnis 
operasional Bank BTN Cabang Kota Semarang.

4) Meminimalisir Kelemahan dan Menghindari Ancaman (W - T)

Strategi ini didasarkan pada kegiatan yang bersifat defensif dan berusaha meminimalkan kelemahan yang ada serta menghindari ancaman. Meminimalisir kelemahan dalam bisnis yang dilakukan untuk menghindari ancaman-ancaman yakni ditempuh dengan menetapkan strategi bisnis yang baru, efektif dan efisien serta memaksimumkan ragam pilihan produk bagi nasabah dengan meningkatkan promosi produk melalui berbagai media. Strategi ini berguna untuk lebih mengetahui apa yang ingin dicapai dalam tujuan bisnis yang telah ditetapkan oleh perusahaan.

\section{KESIMPULAN DAN PENUTUP}

Berdasarkan hasil penelitian yang telah dilakukan maka dapat disimpulkan beberapa hal yakni responsiveness, compliance, empathy, tangiable, reliability dan assurance yang merupakan pola peningkatan pelayanan komunikasi memiliki pengaruh positif terhadap kepuasan nasabah dalam menggunakan jasa perbankan, dengan ini yang harus dimulai dan diperhatikan dengan mengutamakan kebutuhan konsumen atau nasabah, peneliti menemukan data bahwa pelayanan berpengaruh terhadap kepuasan pelanggan, yang berarti bahwa semakin besar pengaruh pelayanan, maka semakin besar pula kepuasan yang dicapai oleh pelanggan tersebut.

Kini BTN terus berupaya meningkatkan pelayanan komunikasinya kepada setiap nasabah agar terus percaya dan setia terhadap perusahaan, secara langsung dan tidak langsung BTN sudah berusaha seoptimal mungkin dalam meningkatkan sarana dan fasilitas fisik para pegawai BTN, membangun rasa kepedulian dan perhatian kepada setiap nasabah, memberikan jaminan untuk setiap nasabah, dan selalu berupaya dalam peningkatan kemampuan dalam memberikan pelayanan dan kelancaran komunikasi kepada nasabah.

Peneliti memberikan saran positif kepada perusahaan dan setiap pelaku usaha perbankan bahwa setiap perbankan harus mampu meningkatkan pelayanan yang lebih baik lagi guna menjaga kualitas produk dan merek untuk menciptakan kepuasan nasabah dengan memudahkan nasabah untuk mendapatkan produk dan pelayanan yang diinginkan. Selain itu, pelayanan prima menjadi perhatian utama bagi nasabah agar konsumen tertarik untuk mencoba dan merekomendasikan produk tersebut kepada orang lain.

Dengan demikian, dapat dikatakan bahwa proses pelayanan komunikasi yang dilakukan oleh Bank BTN Cabang Kota Semarang perlu dioptimalkan kembali agar berjalan secara efektif dan efesien dalam upaya meraih hasil yang maksimal dan baik. Dengan itu strategi-strategi bisnis yang dimiliki perlu dilakukan secara baik agar memberikan pengaruh yang sangat signifikan dalam memberikan kepuasan kepada para nasabah. 
Pelayanan Komunikasi Perbankan Dan...hal.226-243

Hal tersebut dapat diperhatikan pula pada analisis SWOT yang telah dijabarkan bahwa posisi perusahaan dapat menentukan keberhasilan dan kegagalan dalam memberikan kepuasan kepada nasabah, dengan memanfaatkan kekuatan yang dimiliki lokasi yang strategis berdekatan dengan lingkungan UIN Walisongo serta hunian masyarakat dan kekuatan yang perlu diprioritaskan yakni dengan memanfaatkan brand image perusahaan. Perusahaan pun perlu menutup kekurangan yang dimiliki yang menurut para nasabah ialah minimnya faslitas perbankan berupa ATM dan EDC di merchant-merchant serta SDM pemasaran yang minim sehingga feedback kepada nasabah pun belum maksimal.

Peluang dan ancaman yang hadir dari eksternal BTN perlu ditanggapi secara positif untuk menentukan strategi yang bagus dilakukan dan menimbulkan keuntungan bagi perusahaan serta upaya menghindari dan mencegah kerugian yang akan timbul. Skala prioritas begitu penting yakni melihat peluang peluang pasar yang baik dan pertumbuhan inklusi keuangan yang tinggi. Perusahaan pun perlu berinovasi untuk menyaingi produk kompetitor yang variatif. Strategi yang dibuat diharapkan mampu mengembangkan bisnis perusahaan melalui pelayanan komunikasi perbankan Bank BTN Cabang Kota Semarang dalam memberikan kepuasan kepada para nasabah.

\section{DAFTAR PUSTAKA}

Al Arif, M Nur Rianto. (2010). Dasar-Dasar Pemasaran Bank Syariah. Bandung : Alfabeta.
Alma, Buchari. (2007). Manajemen Pemasaran dan Pemasaran Jasa. Bandung : Alfabeta.

Ambarwati, Yulian Belinda. (2014). Pengaruh Kualitas Pelayanan Terhadap Kepuasan Nasabah di PT Bank Central Asia (BCA) Tbk Cabang Undaan Surabaya. Jurnal Akuntansi AKRUAL $(6: 1)$.

Amin, W. T. (1994). Manajemen Suatu Pengantar. Jakarta: Rineka Cipta.

Cahyani, Putri Dwi. (2016). Tingkat Kepuasan Nasabah Terhadap Kualitas Layanan Perbankan Syariah di Yogyakarta. Jurnal Bisnis dan Manajemen (6:2).

Engel, James F. (1992). Perilaku Konsumen. Jakarta : Binarupa Aksara.

Eninurkhayatun, Biyanda, Antono Suryoputro, Eka Yunila Fatmasari. (2017). Analisis Tingkat Kepuasan Pasien Terhadap Kualitas Pelayanan Rawat Jalan Di Puskesmas Duren dan Puskesmas Bergas Kabupaten Semarang Tahun 2017. Jurnal Kesehatan Masyarakat (5:4).

Hasan, A. (2010). Marketing Bank Syariah Cara Jitu Meningkatkan Bank Syariah. Bogor: Ghalia.

Katsir, Ibnu. (2002). Muassasah Qurthubah Tafsir Al-A'zhim. Jakarta: Lentera Hati. 
Kotler, Philip. (2000) Marketing Management. New Jersey : Prentice Hall.

Kotler, Philip. (2007). Manajemen Pemasaran, Edisi 12 Jilid 1 Satu. Jakarta: Indeks.

Kotler, Philip dan Kevin Lane Keller. (2009). Manajemen Pemasaran, Terjemah: Banyamin Molan, Edisi 13. Jakarta: PT. Indeks.

Moenir, H.A.S. (2002). Manajemen Pelayanan Umum di Indonesia. Jakarta : Bumi Aksara.

Mulyadinata. (2015). Pengaruh Kualitas Pelayanan Terhadap Loyalitas Pelanggan PT Bank Tabungan Negara (BTN) Kantor Cabang Bandar Lampung. Jurnal Bisnis Darmajaya $(1: 1)$.

Rangkuti, Freddy. (2009) Analisis SWOT Teknik Membedah Kasus Bisnis. Jakarta : Gramedia.

Sambas, Syukardi. (2015). Sosiologi Komunikasi. Bandung : Pustaka Setia.
Shihab, Quraisy. (2002). Tafsir Al-Mishbah. Jakarta : Lentera Hati.

Tjiptono, Fandy. (1996). Manajemen Jasa, Edisi I, Cetakan Kelima. Yogyakarta : ANDI.

Wibisono, Dermawan. (2006). Manajemen Kinerja. Surabaya : Erlangga.

Yin, R. K. (2008). Studi Kasus-Desain dan Metode. Jakarta : Raja Grafindo Persada.

Yogatama, Yanuar. (2013). Analisis Pengaruh Program Pelatihan Karyawan dan Kepuasan Kompensasi terhadap Kinerja Karyawan dengan Kepuasan Kerja Sebagai Variabel Intervening: Studi Kasus pada PT Bank Tabungan Negara (Persero) Tbk Kantor Cabang Utama Tangerang. Jakarta : Skripsi UIN Syarif Hidayatullah.

Yuliana, R. Hidayat, A. R. dan Tresnati, R. (2016). Pengaruh Bauran Pemasaran Islami (Islamic Marketing Mix) terhadap Peningkatan Jumlah Muzakki pada RZ Kantor Cabang Bandung Antapani. Prosiding Hukum Ekonomi Syariah, 725-731. 